\title{
THE TREATY OF WAITANGI AS AN EXERCISE OF MĀORI CONSTITUENT POWER
}

\author{
Jessica Orsman*
}

This article analyses the Treaty of Waitangi in light of Carl Schmitt's concept of constituent powerthe idea that in a democracy the people hold the power to make fundamental political decisions to determine their form of political existence. It finds that in 1840, Māori, as the holders of constituent power, made a fundamental political decision to share authority between themselves and the Crown. This fundamental political decision is a key element of the New Zealand constitution; limiting potential constitutional changes that would override the substance of the decision, and requiring changes to the current legal framework in order to comply with the decision to share authority. This article focuses solely on the conservative implications of characterising the Treaty as a fundamental political decision. It concludes that only a further exercise of constituent power by Māori can legitimately override or significantly change the fundamental political decision in the Treaty.

\section{INTRODUCTION}

Constituent power is the idea of a group of individuals possessing a "constituting power" to determine the form of a State's political existence - including the model of governance and the authority given to the government. ${ }^{1}$ In a democracy, the people possess constituent power and may exercise it by making fundamental political decisions. ${ }^{2}$ These decisions cannot be overturned except by a further exercise of constituent power. Loughlin has argued that constituent power in this sense does not operate in the English constitutional model because of the doctrine of parliamentary sovereignty. He asserts that resolution of the issue as to how the people might choose their own governance was subverted during the constitutional crises in the 17th century - culminating in the

\footnotetext{
* Submitted as part of the LLB(Hons) programme at Victoria University of Wellington. I would like to thank Dr Joel Colón-Ríos and Dr Rayner Thwaites for their comments and support.

1 Carl Schmitt Constitutional Theory (Duke University Press, Durham, 2007).

2 Ibid at 77.
} 
crowning of King William and Queen Mary after the 1688 revolution. ${ }^{3}$ Aspects of New Zealand's constitutional model derive directly from English constitutional history, including the parliamentary sovereignty model initially introduced by the Bill of Rights $1688 .{ }^{4}$ Arguably, however, New Zealand's constitution does contain a source based on an exercise of constituent power, namely the Treaty of Waitangi.

This article analyses the Treaty of Waitangi (the Treaty) in light of the concept of constituent power in two ways. Parts II and III of the article illustrate that the Treaty was a fundamental political decision made by Māori exercising constituent power, determining the division of authority in New Zealand. The remaining parts of this article argue that any significant derogation from this fundamental political decision contained in the Treaty is prohibited unless sanctioned by further exercises of Māori constituent power. This second application of constituent power is relevant in two ways: it limits future potential constitutional changes that are inconsistent with the fundamental political decision in the Treaty; and it points out instances in the status quo that are inconsistent with the fundamental political decision and which need to change in order to comply with the decision in the Treaty. This article focuses solely on the limitations on future potential constitutional changes.

Overall, the purpose of this article is to show, through the theory of constituent power, that the Treaty provides a significant limitation on the New Zealand constitutional set-up and juridical system. This conclusion puts us in a different position to England, as the Crown in New Zealand must work within the framework of the foundational exercise of constituent power.

\section{CONSTITUENT POWER}

In basic terms, the constituent power is the power or will to make a constitution, where that power exists independently of, and pre-dates the constitution. In contrast, the powers contained within a constitution to make laws and exercise authority are the constituted powers.

\section{A Schmitt's Conception of Constituent Power}

Schmitt's premise is that a constitution comes about and is valid when a body possessing political will makes a fundamental decision about the form and order of its political existence: "The constitution is valid by virtue of the existing political will of that which establishes it". ${ }^{5}$ The substance of the decision equates to the substance of the constitution.

3 Martin Loughlin "Constituent Power Subverted: From English Constitutional Argument to British Constitutional Practice" in Martin Loughlin and Neil Walker (eds) The Paradox of Constitutionalism: Constituent Power and Constitutional Form (Oxford University Press, New York, 2007) 25.

4 David Williams "The Constitutional Status of the Treaty of Waitangi: An Historical Perspective" (1990) 14 NZULR 9 at 10.

5 Carl Schmitt Constitutional Theory, above n 1, at 76. 
In a democracy, the people hold the political will and thus power to make a political decision. Thus, the people hold constituent power. Schmitt defines the people as those who as a unity are capable of political action. This requires some consciousness by people of their political existence, as opposed to their cultural or ethnic existence. ${ }^{6}$

An essential feature of constituent power is that the constitution is distinguished from the constitutional laws. According to Schmitt, all the constitutional laws, norms and ordinary laws flowing from a fundamental political decision are only valid if based on the decision and within its context. ${ }^{7}$ This then leads to an important difference between what is a "constitutional change" as compared to what is "constitution-making". ${ }^{8}$ The former refers to an amendment, addition or elimination of constitutional laws (the secondary rules/norms), and the latter involves a change to the form of political organisation such that it is a fundamental political decision (the primary/higher norm).

Schmitt illustrates the distinction by referring to the fundamental political decisions in the German 1919 Weimar Constitution. For instance, the decision for democracy is provided for by the clauses in art 1 of the Weimar Constitution, which explicitly states that, "State authority derives from the people" and "the German people provided itself this Constitution". ${ }^{9}$ The decision to replace the monarchy with a republic is also a political decision, declared in art 1 by "The German Reich is a republic". ${ }^{10}$ Likewise, art 2 determines a "federal-state structure for the Reich". ${ }^{11}$ There is a further decision that the legislative authority and government be in a Parliamentary representative form. Lastly, the Weimar Constitution establishes the liberal State to entrench certain principles, fundamental rights and the separation of powers. ${ }^{12}$ Together these individual fundamental political decisions lead to the characterisation of the Weimar constitution as a "democratic republic with a federal-State structure". ${ }^{13}$ These foundations of German political organisation can be contrasted with all the "additional norms, enumerations, and detailed delimitations of competencies", ${ }^{14}$ which

6 Ibid at 127

7 In this way Schmitt argues the concept of constituent power still fits within positivist jurisprudence - the fundamental political decision stemming from an exercise of constituent power is the primary rule, and the constitutional laws and other laws are secondary rules with authority resting in adherence to that primary rule. See Carl Schmitt Constitutional Theory, above n 1, at 88.

8 Ibid at 80.

$9 \quad$ Ibid at 78

10 Ibid.

11 Ibid.

12 Ibid.

13 Ibid.

14 Ibid. 
were constitutional laws that could be amended by the procedures set out in art 76 of the Constitution. However, according to Schmitt, the basic fundamental decisions outlined above could not be changed by Article $76 .{ }^{15}$ So for example, the German representative Parliament could not have voted by a two thirds majority to transform the republic back into a monarchy. ${ }^{16}$ Likewise, although some intrusions on the basic rights guaranteed by the constitution might be acceptable constitutional changes, the abolition of such guarantees entirely would encroach on the territory of constitution remaking. ${ }^{17}$

In the case where amendments would amount to overriding a fundamental political decision, the people holding constituent power, rather than an already constituted legislature, must make the "changes". ${ }^{18}$ This is because a constitution is inviolable - except as described below - the fundamental political decisions that are its substance must be preserved. Only another exercise of constituent power can overturn a prior fundamental political decision created by an exercise of constituent power. This raises an important point that the constituent power or political will is not eliminated, or "absorbed," by the birth of a constitution. ${ }^{19}$ It remains alongside and above the constitution, ready to resurface in times when a fundamental political decision is remade: "The instituted society is always subject to the subterranean pressure of the constituting society". ${ }^{20}$ This goes back to the fundamental precept of constituent power that it is the higher norm; above the constituted order. Schmitt also asserts that where there are gaps or ambiguities in the constitutional law, the constituent power may be required to clarify the answer. ${ }^{21}$

\section{B Reasons for Using Constituent Power Theory}

This section sets out several reasons why Schmitt's theory of constituent power is a useful tool to engage in the context of the New Zealand constitution and the Treaty of Waitangi. First, constituent power is generally useful as a method through which to assess the democratic legitimacy of a constitution, which may be applied to New Zealand. ${ }^{22}$ Secondly, constituent power, with its

15 Ibid.

16 At 79.

17 At 81.

18 At 80.

19 Joel Colón-Riós "The Legitimacy of the Juridical Constituent Power, Democracy, and the Limits of Constitutional Reform" (2010) 48 Osgoode Hall LJ 199 at 205.

20 Cornelius Castoriadis Philosophy, Politics, Autonomy: Essays in Political Philosophy in David Ames Curtis (ed) (Oxford University Press, Oxford, 1991) 152-153.

21 At 126.

22 Joel Colón-Riós "New Zealand's Constitutional Crisis" (2011) 24 NZULR 448. 
extra-juridical point of view, is appropriate for the Treaty of Waitangi, where debate should not be confined to the Treaty's meaning within the existing legal framework. ${ }^{23}$

\section{Link to democratic legitimacy}

Kalyvas argues that the degree of participation and inclusion in the framing of a new constitutional order can be used to evaluate or critique the validity and legitimacy of the order that has been created, and the manner of its creation. ${ }^{24}$ In other words, constituent power is a lens through which to view the democratic legitimacy of a constitution - and its binding power over those it purports to address. ${ }^{25}$ In addition, following Schmitt's argument that constituent power can never be eliminated, the presence or absence of opportunities for the exercise of constituent power can also be used to assess the democratic legitimacy of the legal order post-creation. Such opportunities should exist for constituent power to resurface - either in order to question the entire existing constitutional arrangement, or to participate in constitutional changes that amount to a fundamental political decision. ${ }^{26}$ Fundamental changes to the already established order that were undertaken without an exercise of constituent power would also not be considered democratically legitimate. To enable constituent power to resurface, it has been argued that political rights and institutions that promote popular participation must be available. ${ }^{27}$ Further, if the people exercised constituent power but in doing so made fundamental political decisions to abolish such institutions, the self-limiting constitution created would not be very democratically legitimate. ${ }^{28}$

The relevance of such a critique might be questioned when few real examples exist of constitution-making that are perfectly consistent with its ideals and values. However, constituent power is still a useful tool because it offers a framework for how constitutions should be framed and reframed in a democracy. ${ }^{29}$ Further, a constitution need not follow the binary logic of being either wholly democratically legitimate or not - arguably the democratic legitimacy of a constitution can be seen to be a matter of degree. A State may be prepared to sacrifice some democratic legitimacy in aspects of its constitution in favour of other ideals. However, States should at least be aware of these sacrifices, and analysing a constitution through constituent power can point out where they have

23 Carwyn Jones "Book review: The Treaty of Waitangi in New Zealand's Law and Constitution" (2009) 7 NZJPIL 367 at 369.

24 Andreas Kalyvas "Popular Sovereignty, Democracy, and the Constituent Power" (2005) 12(2) Constellations 223 at 238.

25 Ibid at 237.

26 Joel Colón-Riós "New Zealand's Constitutional Crisis", above n 22, at 456.

27 Ibid.

28 Ibid.

29 Ibid at 455 . 
occurred. ${ }^{30}$ It is also useful to know in the future how the State could incorporate more opportunities for the exercise of constituent power in its existing constitutional order, or in the framing of a new order, and thus claim (more) democratic legitimacy. ${ }^{31}$

\section{Application to the Treaty of Waitangi}

There is a further justification for applying the concept of constituent power specific to the New Zealand context: the theory of constituent power assesses the role of the Treaty in the constitution from an extra-juridical perspective, which allows for a more diverse consideration of the constitutional dynamics surrounding the Treaty. Much of the previous work on the Treaty has focused on its legal or constitutional role from the conventional position that absolute sovereignty vests with the Crown and that the Treaty is subject to the ordinary laws of the State. ${ }^{32}$ In a recent example, Matthew Palmer has assessed the role of the Treaty in New Zealand's constitution in terms of "... how the Treaty currently affects and reflects the exercise of public power in New Zealand". 33 Palmer's approach is a realist one and aims to uncover the place of the Treaty in the real-life workings of New Zealand's constitutional arrangements - so that then we might know as a pragmatic matter how to change the constitutional role of the Treaty if so desired. ${ }^{34}$ This approach has many advantages, not least its utility in the courts and government; however, it has been criticised for not including an adequate Māori perspective, in particular to inform the scope of the constitutional theories relied on. ${ }^{35}$ Several Māori scholarly approaches to the Treaty, such as that published by Moana Jackson, do not regard the Treaty as being subject to the existing legal framework. Jackson argues that Māori retained power and authority through the Treaty, regardless of the recognition actually granted to the Treaty in the existing legal framework. ${ }^{36}$ This view cannot be reconciled with an analysis that moves only within the bounds of the existing legal framework, which itself is not necessarily constitutional. This article does not claim that the theory of constituent power is a Māori viewpoint or theory itself, but it argues that the theory provides more scope for diverse views on the New Zealand Constitution, where this critically includes Māori

30 Ibid at 450 .

31 Ibid. This is particularly the case in New Zealand if a written constitution emerged in the future.

32 FM Brookfield "The Treaty, The 1840 Revolution and Responsible Government" (1992) 5 Canta LR 59; Paul McHugh The Māori Magna Carta: New Zealand Law and the Treaty of Waitangi (Oxford University Press, Auckland, 1991).

33 Matthew SR Palmer The Treaty of Waitangi in New Zealand's Law and Constitution (Victoria University Press, Wellington, 2008) at 234.

34 Carwyn Jones "Book review: The Treaty of Waitangi in New Zealand's Law and Constitution", above n 23, at 369 .

35 Ibid.

36 Moana Jackson "The Treaty and the Word: The Colonization of Māori Philosophy" in Graham Oddie and Roy Perrett (eds) Justice, Ethics, and New Zealand Society (Oxford University Press, Auckland, 1992) 1. 
perspectives of the Treaty. An analysis of the Treaty of Waitangi in terms of constituent power includes a Māori perspective by asking what Māori were assenting to and/or deciding by signing the Treaty, rather than analysing how the Treaty should legally be interpreted applying the common law and constitutional arrangements of the New Zealand State.

\section{Participation - the Core Principle of Constituent Power}

A key issue is when an exercise of constituent power will promote democratic legitimacy in the framing of a new constitution. The principles that determine what amounts to a democratically legitimate exercise of constituent power have been described as "immanent" or "implicit" principles, arising by virtue of the instituting act itself. ${ }^{37}$ As Kalyvas emphasizes, a literal analysis of the word "constitute" means "to found together". ${ }^{38}$ Participation of the prospective addressees is at the core of constituent power and democratic constitution-making. ${ }^{39}$

Kalyvas describes qualitatively the requirement of participation as a reciprocal process, which the participants must rely on in order to achieve an inclusive constitution that appeals to all the participants. ${ }^{40}$ This reciprocal process involves "... symmetry, autonomy, equality, mutuality, disagreement, discussion and inclusiveness" between the people involved in framing the fundamental political decisions. ${ }^{41}$ Essentially, it provides for the fact that although individuals share the same aim of establishing new foundations, it is likely they might disagree on substantive issues so it is necessary to promote equality in the constitution-making process. The requirement of participation would not be met if individuals were forced to accept a constitution under duress that went the beyond ordinary pressures to compromise, or if individuals had no opportunity to directly or by representation be involved in the process.

As for specific mechanisms of participation, including the use of representation, Schmitt envisaged several processes (in a modern democratic context) that would satisfactorily recognise his concept of constituent power:

(1) A democratically elected constitution-making assembly that passes the constitution and constitutional laws by its own majority vote;

(2) A democratically elected constitution-making assembly that drafts the constitution and constitutional laws that are passed by a referendum vote;

37 Andreas Kalyvas "Popular Sovereignty, Democracy, and the Constituent Power", above n 24, at 238.

38 At 235

39 Ibid at 238.

40 Ibid.

41 At 236. What the reciprocal process involves is further illustrated in Part III of this article when the participation of Māori in signing the Treaty of Waitangi is analysed. 
(3) A constitutional assembly that submits the drafted constitution to each federal State for assent; and lastly

(4) A general popular vote on a proposed constitution or constitutional change.

Representation of the will of the people through elected officials is a valid form of participation in the exercise of constituent power, as long as the elected assembly is democratic and distinct from an already elected legislature or instituted body. Arguably, the second scenario suggested by Schmitt is the most democratically legitimate exercise of constituent power because the people are democratically represented in the framing of the fundamental political decision and they vote directly to adopt the decision.

However, it should be remembered that Schmitt's proposition is that the constituent power is a power that exists above the existing legal order. ${ }^{42}$ It would seem contrary to the concept itself to impose strict prescribed or regulated procedures so that the legal framework could bind the exercise of constituent power. Nonetheless, certain procedures may be required to enable effective participation by the people and facilitate the exercise of their constituent power in a democratically legitimate manner.

\section{Constituent Power in an Unwritten Constitutional Context}

Constituent power as conceptualised above fits less easily in the context of an unwritten constitutional model than its written counterparts. It contemplates fundamental political decisions recorded in written form and (usually) accorded supreme law status. It may nevertheless be possible to imagine Schmitt's theory of constituent power operating in an unwritten context, as long as the basic principles of the theory were present. Perhaps one could imagine an indigenous culture where tribal political structure was by the agreement of the collective political will, but this was recorded in oral tradition because the concept of recording the structure in a document is unrecognised. For example, Henderson describes the political existence of the indigenous people of Canada: "First nations jurisprudences, then, rely on ceremonial performance and oral traditions rather than on political assemblies, written words, and documents". ${ }^{43}$ In this scenario it is arguable that Schmitt's notion of constituent power is present because there is a fundamental decision on the form of political organisation made by those with political will: it is just recorded and recognised by different means than a constitutional document.

However, in an unwritten constitution where the pure doctrine of parliamentary sovereignty operates, constituent power cannot work in the way Schmitt conceptualises. This is because

42 Carl Schmitt Constitutional Theory, above n 1, at 130.

43 James Youngblood Henderson First Nations Jurisprudence and Aboriginal Rights: Defining the Just Society (Native Law Centre, University of Saskatchewan, Saskatoon, 2006) at 167. 
parliamentary sovereignty conflates constituent power with constituted power. ${ }^{44}$ Parliament ends up possessing both types of power as a self-constituting institution. Political sovereignty (the concept for the people or community as sovereign) is reduced to the people determining the law through parliamentary representatives. ${ }^{45}$ This is not a true exercise of constituent power because, as explained above, constituent power requires fundamental political decisions and the constitution to be made outside of an established legal institution. Constituent power is higher than and separate from the established legal institutions: "All constitutionally constituted powers and competencies are based on the constitution-making power. However, it can never constitute itself in terms of constitutional law". 46 Therefore according to Schmitt, the English Parliament, although legally able to do so, could not make fundamental political decisions that were unsupported by the general political will - such as deciding to transform England into a Soviet State (if it were to be in compliance with constituent power).

\section{NEW ZEALAND: THE TREATY OF WAITANGI AND CONSTITUENT POWER}

Martin Loughlin has argued that the English Westminster constitutional monarchy does not comply with constituent power because Parliament exercises the constituent power for the people without their direct participation. His thesis is that the question of the English people deciding on their own form of governance and authority of legal institutions was never addressed, but rather was subverted in the constitutional crises of the 17th century when the Crown was reinstated with the Crown-in-Parliament. ${ }^{47}$ Many of New Zealand's constitutional structures derive directly from the English constitutional model, including parliamentary sovereignty initially introduced by the Bill of Rights $1688 .{ }^{48}$ Therefore, one might be inclined to put New Zealand on the same level as England as regards lack of constituent power, and democratic legitimacy. However, there is at least one key difference between the origins of the English constitution and the New Zealand Constitution; namely the signing of the Treaty of Waitangi in 1840 - a compact between over 500 Māori chiefs and the Crown, which marks the beginning of the New Zealand State.

This part of the article analyses the signing of the Treaty as an exercise of constituent power by Māori, concluding that it contains a fundamental political decision by Māori to share authority with the Crown. In so doing, it is largely reliant on previous historical analysis by scholar Claudia

44 Andreas Kalyvas "Popular Sovereignty, Democracy, and the Constituent Power", above n 24, at 229.

45 Ibid.

46 Carl Schmitt Constitutional Theory, above n 1, at 128.

47 Martin Loughlin "Constituent Power Subverted: From English Constitutional Argument to British Constitutional Practice", above n 3.

48 David Williams "The Constitutional Status of the Treaty of Waitangi: An Historical Perspective", above n 4, at 10 . 
Orange and others. The factual accounts will be well known by most readers but are rehearsed in this section to explain how they support the characterisation of the Treaty as an exercise of constituent power.

\section{A Māori as Holders of Constituent Power}

The first consideration to be made is who held constituent power in 1840 and whether Māori at the time could fit Schmitt's conception of a people able to make a fundamental political decision. Prior to 1840, estimates of the Māori population ranged between 90,000-200,000. The settler population at the time was approximately 2,000 people. ${ }^{49}$ Māori were organised in tribes or iwi, predominantly in the North Island, with chiefly leadership based on a mixture of heredity and achievement in leadership. ${ }^{50}$ Although Māori were part of the same society in terms of a shared belief system, culture and language, ${ }^{51}$ the geographic and social fragmentation of the society into separate tribes could potentially prevent Māori from satisfying Schmitt's view of people with an acknowledged political existence. It does not necessarily follow, however, that political will has to manifest itself in a political existence with centralised or collective governance. It is arguably sufficient that Māori recognised their political existence as a network of distinct tribal groups or political entities, each with authority. Further proof of political awareness before the signing of the Treaty is arguably reflected in the Declaration of Independence, signed by 52 hereditary chiefs and heads of tribes (from North Cape to Thames) between 1835-1839. ${ }^{52}$ The Declaration, orchestrated in part by James Busby, purported to declare New Zealand as an independent State under the designation of the United Tribes of New Zealand; and was recognised by the Colonial Office. The motivation behind the British influence and support of the Declaration is explained by the fact that it set up a body that, by international law standards of the time, could be capable of possessing and subsequently ceding (by Treaty) sovereignty to the British. Following this, a final point that also supports Māori capacity to make a fundamental political decision is the fact that the British, in seeking to negotiate cession of Māori sovereignty, viewed the Māori as a people with political will that stood in the way of British settlement.

\section{B The Fundamental Political Decision Contained in the Treaty}

The Treaty is not the embodiment of a typical written constitution. It does not really set out "central rules and higher procedures" for a newly constituted New Zealand State. ${ }^{53}$ Nor does it

49 Claudia Orange The Treaty of Waitangi (Bridget Williams Books Ltd, Wellington, 2011) at 17.

50 Ibid.

51 Ibid.

52 Ibid at 238.

53 See Andreas Kalyvas "Popular Sovereignty, Democracy, and the Constituent Power", above n 24, for a discussion of "central rules and higher procedures". 
constitute specific institutions of government. Although art 3 gives New Zealanders the same rights and duties as British citizens, it does not specify how the Crown will protect them, or entrench the rights as supreme law. Article 2 sets out the right to pre-emptive purchase of Māori land by the Crown, but again this cannot really be said to be a higher procedure or entrenched right. However, what the Treaty does arguably contain is an agreement on the authority to be held respectively by Māori and the Crown in New Zealand.

This agreement is contained within arts 1 and 2 of the Treaty. Following Professor Kawharu's translation of the Māori text, art 1 provides for the chiefs to "give absolutely to the Queen of England forever the complete government over their land". ${ }^{54}$ This is qualified in art 2 whereby the Queen agrees to protect Māori "in the unqualified exercise of their chieftainship over their lands, villages and all their treasures". ${ }^{55}$ It is argued that the effect of Māori assent to these provisions was to agree to the Crown acquiring governing authority over New Zealand, but to retain authority by Māori over their people and land according to customary law (tikanga Māori). ${ }^{56}$ The differences between the English and Māori versions of the Treaty and interpretational issues have been used to dispute this conclusion. However, there are several reasons to conclude that preservation of Māori authority to self-govern is the correct interpretation of the agreement in the Treaty. First, following international treaty-making principles, indigenous text should be preferred, and Professor Kawharu's widely accepted translation of the Māori text points to the retention of Māori chieftainship (te tino rangatiratanga) alongside the Crown's authority. ${ }^{57}$ Further, the Māori version of the Treaty should be favoured because Māori were the holders of the constituent power, and thus it is the Māori viewpoint that is determinative. As Paul McHugh has argued, there is strong evidence to suggest that the Māori political will was to agree to Crown authority without giving up their authority to self-govern. ${ }^{58}$ Lastly, it might be argued that the agreement by Māori was not solely expressed in the assent to the written text of the Treaty, but was to an extent also recorded in oral tradition, around the process of the presentation and signing of the Treaty. Claudia Orange has emphasised the importance of such traditions in Māori political culture, and the role that such traditions played in the Treaty signing process. ${ }^{59}$ Accounts of the Māori understanding of the division of governing authority in the Treaty, from oral discussions of the Treaty both between Māori and the settlers' representatives and amongst Māori before its signing, support the retention of te tino rangatiratanga

54 Hugh Kawharu "Kawharu Translation" Waitangi Tribunal < www.waitangi-tribunal.govt.nz>.

55 Ibid.

56 Paul McHugh The Mãori Magna Carta: New Zealand Law and the Treaty of Waitangi, above n 32, at 46.

57 FM Brookfield "The Treaty, The 1840 Revolution and Responsible Government", above n 32, at 60.

58 Paul McHugh The Mãori Magna Carta: New Zealand Law and the Treaty of Waitangi, above n 32, at 46.

59 Claudia Orange The Treaty of Waitangi, above n 49, at 53. 
as a limitation to the authority given to the Crown. ${ }^{60}$ This article adopts the interpretation of the Treaty as a decision to share authority as articulated by Brookfield: "The Treaty effected both a cession of governance (kawanatanga) to the Crown and a reservation of authority (rangatiratanga) to the signatory Chiefs". 61

The assent by Māori to the authority split in the Treaty can be seen as Māori making a fundamental political decision. This is because the assignment of governing authority in a State very much goes to the core of the form of its political organisation and existence. Schmitt's identification of the provision in the Weimar constitution passing governing authority from the monarchy to a representative Parliament as a fundamental political decision supports this characterisation. The Treaty contains an analogous fundamental political decision allotting authority in the new State, in this case both to the Crown and to Māori. The fact that the Treaty contains only one fundamental political decision - the share of authority in the State - does not negate the decision as an element of the New Zealand Constitution. As apparent from his example of multiple fundamental decisions in the Weimar Constitution, there is nothing in Schmitt's conception of constituent power to say there must be only one fundamental political decision framing every aspect of the legal order constituted. This is especially obvious when Schmitt envisages constituent power should again manifest to legitimise fundamental changes to the existing order. In other words, fundamental political decisions do not have to encompass a decision for the whole political order; they can also cover individual aspects of that order.

\section{Participation by Māori in the Decision}

In respect of the drafting of the Treaty texts, there was no direct participation by Māori. James Busby drafted the essentials of the English version, and Henry Williams and his son translated the final English version into the Māori version. ${ }^{62}$ However, the content, especially the protection of Māori interests and control of the Crown over British nationals who were already in New Zealand and causing trouble, can be traced in part to requests that had been expressed by some chiefs to Busby. On 5 February 1840, the meeting at Waitangi was held. Following the reading of the English text by Hobson, and the Māori text by Williams, the Māori chiefs then had the opportunity to respond and question what had been presented. ${ }^{63}$ Various chiefs spoke for five hours in the Māori custom of whaikōrero. Many raised concerns over the protection of Māori land, and some directed attacks at particular Pākehā for controversial land transactions, who then answered those claims. Kalyvas' reciprocal process of participation, involving "... symmetry, autonomy, equality, mutuality, disagreement, discussion and inclusiveness", could be said to be operating to a certain degree before

60 Ibid at 61.

61 FM Brookfield "Republican New Zealand: Legal Aspects and Consequences" [1995] NZ L Rev 310 at 316.

62 Claudia Orange The Treaty of Waitangi, above n 49, at 47.

63 Ibid at 53. 
and during the fundamental political decision at Waitangi. ${ }^{64}$ Māori were autonomous, and acted freely in signing the Treaty - Māori did not accept it under threat of attack by the British. Further, Māori were not excluded from influence in the framing of the Treaty - arguably, the Māori text was strategically framed and presented on terms they would accept. If the fundamental political decision is taken from the Māori text and the Māori understanding of the Treaty as expressed through the discussions and debate at Waitangi, for the reasons argued above, the participation of Māori equates to a legitimate exercise of constituent power by them.

Eventually, over 500 chiefs signed the Māori version of the Treaty. ${ }^{65}$ Although the representation of Māori was via tribal chiefs who were not democratically elected, it is submitted that this should be accepted as a valid mode of representation. The Treaty was not signed in the modern democratic context in which Schmitt envisaged methods for representation in constitutionmaking, but rather in the context of an indigenous culture with its own customs for individual participation in political existence, which should be respected. Arguably, the mode of representation in Māori customary practice and political existence in 1840 was democratic for the purposes of participation in the exercise of constituent power, because it promoted direct and personal accountability to hapū or iwi, which were based around genealogical connections, even though appointment was by other customs rather than by formal elections. ${ }^{66}$

Importantly, not all tribes agreed to sign the Treaty. However, in all of the constitution-making methods proposed by Schmitt, there is room for dissent by some constituent assembly members or some of the people in a popular vote, within a valid exercise of constituent power. Therefore by analogy, it is sufficient that there was agreement by most Māori in making the fundamental political decision, despite the existence of some dissent.

\section{Conclusion}

The finding that the Treaty of Waitangi contains a fundamental political decision by Māori exercising constituent power has several ramifications. First, it means that the substance of that decision by Māori - to pass authority to govern in New Zealand to the Crown save for the authority over their own people according to their customary law - is a building block of the New Zealand constitutional set-up. This clearly sets us apart from the constitutional set-up in England, where there was no initial exercise of constituent power to decide a fundamental delegation of authority in the English Constitution. In terms of democratic legitimacy at least, the foundational aspect of the New Zealand constitution seems to have a different source of democratic legitimacy than the English State because there was effective participation by the people possessing constituent power.

64 Andreas Kalyvas "Popular Sovereignty, Democracy, and the Constituent Power", above n 24, at 236.

65 Paul McHugh The Māori Magna Carta: New Zealand Law and the Treaty of Waitangi, above n 32, at 1.

66 ET Durie "Location of Authority in Custom Law" (privately circulated paper 1994, reproduced in Mai I Te Ata Hapara Conference, Te Wananga o Raukawa (Otaki), August 2000) at 34-41. 
In line with this conclusion, Māori assent to the Crown's share of authority is often cited as a legitimising factor of the Crown's authority. For example, Brookfield asserts it is the Māori assent to the Treaty that adds legitimacy to the Crown's authority because it represents "at least a significant expression of indigenous assent to some measure of Crown rule". 67

\section{THE POLITICAL CONSTITUTIONAL EFFECT OF THE FUNDAMENTAL POLITICAL DECISION IN THE TREATY}

The development of the New Zealand constitution from the time of the Treaty (the exercise of constituent power) had to fit with the fundamental political decision in the Treaty. However, the nature of the limitation that the fundamental political decision in the Treaty imposes is not a directly legal one. This is because under Schmitt's theory of constituent power, the power to constitute operates in an "extra-legal zone"; 68 it is not subject to an existing legal framework but nor is it enforceable as a rule of law in that framework. This does not mean that fundamental political decisions, like the one contained in the Treaty, do not have a significant impact and influence on an existing legal order. Fundamental political decisions are higher norms from which ordinary and legal norms derive authority, albeit political and constitutional authority.

The idea that a constitution can contain sources which have political authority rather than direct legal authority is already recognised. For example, in defining the constitution in the context of New Zealand's unwritten model, Andrew Sharp describes it as: ${ }^{69}$

...that system of legal rules and politically-effective, if not legally enforceable, conventions that govern the behaviour of the holders of public office in their relationships with each other and with the people they govern.

The Westminster constitutional model of New Zealand (and England) is full of rules and conventions that exist solely in a political sphere. This stems in part from the unwritten characteristic of these models whereby the substance of the constitution is not encapsulated in one written document. Philip Joseph summarises the New Zealand constitution in the following manner: ${ }^{70}$

The Constitution is located in a range of legal and extralegal sources, including the statutes of the British and New Zealand Parliaments, the common law, Constitutional convention, the law and custom of Parliament, the great legal commentaries (such as those of Blackstone and Dicey), customary

67 FM Brookfield "The Treaty, The 1840 Revolution and Responsible Government", above n 32, at 63.

68 Andreas Kalyvas "Popular Sovereignty, Democracy, and the Constituent Power", above n 24, at 227.

69 Andrew Sharp "Constitutionalism" in Raymond Miller (ed) New Zealand Governments and Politics (4th ed, Oxford University Press, Auckland, 2006) 103 at 103.

70 Philip A Joseph Constitutional and Administrative Law in New Zealand (3rd ed, Brookers, Wellington, 2007) at $1-2$. 
international law, the principles of the Treaty of Waitangi, and a host of Westminster traditions embedded in British Constitutional history.

\section{A The Fundamental Political Decision as a Constitutional Convention}

This section discusses how within the New Zealand constitution the fundamental political decision in the Treaty operates as an extra-legal source. It argues that its effect is analogous to a constitutional convention, which imposes a binding obligation on the Crown to share authority with Māori, and which will incur a political sanction if breached.

\section{Constitutional conventions}

Constitutional conventions are examples of a significant extra-legal constitutional source. They are binding rules, the breach of which is just as unconstitutional as a breach of a constitutional law, although the enforcement and the sanctions imposed on the breaches differ. ${ }^{71}$ Conventions are unwritten in the sense that they are not on the statute books as law, but the Cabinet Office Manual has encapsulated many key conventions in writing. ${ }^{72}$ Whereas constitutional laws are enforceable in a court of law, conventions are not. Rather, there are political sanctions for a breach of convention, usually enforced within the political body - the House of Representatives. ${ }^{73}$ In some cases, a breach of convention will lead to legislation cementing and clarifying the convention, making it legally enforceable. ${ }^{74}$ Rules of convention arise from the repeated course of behaviour by constitutional actors. For a practice to have status as a constitutional convention, it is necessary that there is an expectation that the particular behaviour will continue because the actors consider themselves bound to follow it. ${ }^{75}$

Following Schmitt's theory, some constitutional conventions would be equivalent to fundamental political decisions, and thus core constitutional principles, while others are merely changeable constitutional norms. One of the primary examples of a constitutional convention in New Zealand is the expectation that the Governor-General will exercise his or her executive powers only on the advice of responsible ministers, who are accountable to Parliament. ${ }^{76}$ This convention unarguably has the comparable constitutional status of a fundamental political decision, because it

71 Colin Turpin British Government and the Constitution (6th ed, Cambridge University Press, Cambridge, 2007) at 156.

72 Cabinet Office Cabinet Manual 2008.

73 Colin Turpin British Government and the Constitution, above n 71, at 156.

74 John McGrath "The Harkness Henry lecture: The Crown, The Parliament and the Government" (1999) 1 Wai L Rev 19 at 20-21.

75 Colin Turpin British Government and the Constitution, above n 71, at 159.

76 Bruce Harris "Constitutional Change" in Raymond Miller (ed) New Zealand Government and Politics (4th ed, Oxford University Press, 2006) 115 at 115. 
represents the key principle that the Monarchy, and their representative the Governor-General, do not in fact exercise law-making power that they hold, rather it is representative Parliament that exercises that power in reality. ${ }^{77}$ If the Governor-General attempted to exercise his or her discretion and refused to sign a Bill on the advice of a responsible minister, New Zealand would face a constitutional crisis. While legally plausible, the political will is not for the Monarchy to exercise law-making power and there would be real political consequences if they were to do so. On the other hand, there are other constitutional conventions that do not go to the core of the Constitution, and could be breached without constitutional crisis. For example, the confidentiality and unanimity aspects of the constitutional convention that Cabinet Ministers are collectively responsible have been less strictly enforced in the face of Official Information Act 1982 requests, and also the changes that the Mixed Member Proportional voting system (MMP) brought to the functioning of Cabinet by including Cabinet Ministers from multiple parties. ${ }^{78}$

\section{The fundamental political decision}

One way to understand the fundamental political decision contained in the Treaty within the constituted New Zealand legal order is to see the decision as a constitutional convention that is a core element of the Constitution. The creation of the fundamental political decision is of course not analogous to the creation of a convention (by common practice); however, what is analogous is the effect of the fundamental political decision. In this way, the decision in the Treaty puts a binding obligation on those exercising public power to adhere to the principle of sharing authority between Māori and the Crown. If decision-makers do not uphold the fundamental political decision, Māori can direct significant and justified political rebuke at the decision-makers for the breach of this obligation. Other authors have recognised the extra-legal significance and effect of the Treaty as a constitutional source. For example, Matthew Palmer suggests that since the 1970s the increased recognition of the political and symbolic significance of the Treaty as the source of the Crown's own authority has led to the re-interpretation by government of the Treaty over that time. ${ }^{79}$ As Palmer points out, this reinterpretation has transformed the legal framework. There are now numerous references to the principles of the Treaty in statute, obliging those who exercise public power to have regard to the principles in their decision-making. The statutory obligations often include a duty to consult Māori. ${ }^{80}$ Arguably, this transformation amounts to the legalisation of a constitutional convention, as described above, so that it becomes legally enforceable.

77 Philip A Joseph Constitutional and Administrative Law in New Zealand, above n 70, at 223.

78 Geoffrey Palmer and Matthew Palmer Bridled Power (4th ed, Oxford University Press, South Melbourne, 2004) at 86-87.

79 Matthew SR Palmer The Treaty of Waitangi in New Zealand's Law and Constitution, above n 33, at 247.

80 Ibid at 276 


\section{B The Fundamental Political Decision as a Conservative and Aspirational Principle}

Applying Schmitt's theory of constituent power to the fundamental political decision is relevant today in two ways. First, the constitutional power of the fundamental political decision operates in a conservative way to restrict the type of potential constitutional changes and law-making decisions with reference to the decision to share authority between the Crown and Māori. Constitutional changes or laws that would override that original fundamental political decision require a further exercise of constituent power by Māori according to Schmitt's theory. Secondly, there will be ways in which the status quo does and does not respect the substance of the fundamental political decision. This application is aspirational in the sense that it shows the policies required to achieve compliance with the decision to share authority. The remainder of this article deals with the effects of the fundamental political decision as a conservative principle. The aspirational aspects of the fundamental political decision require a detailed account of the nature of shared authority, calling for a separate article.

\section{LIMITATIONS ON POTENTIAL NEW ZEALAND CONSTITUTIONAL CHANGES}

In December 2010, the Government announced the establishment of a constitutional review, to look into a wide range of constitutional matters including public interest in changing New Zealand's constitutional arrangements. ${ }^{81}$ The changes to be investigated by the Constitutional Review Committee included: electoral issues, such as the length of Parliament's term and its size; Māori representation in Parliament and in local government bodies; the place of the Treaty in New Zealand's constitutional arrangements; the need for a written constitution; and whether New Zealand should become a republic. ${ }^{82}$

As discussed above in Parts II III of this article, Schmitt views the constitution as a collection of fundamental political decisions or elements. These key elements relate to one another, and significant changes made to one of the elements might unacceptably affect the operation of another element. It is likely that at least some of the contemplated changes in the Constitutional Review, detailed below, would be in danger of infringing the fundamental political decision contained in the Treaty to share authority with the Crown. The purpose of this section is not to argue against constitutional change, but rather to demonstrate that changes that are inconsistent with the fundamental political decision require a further exercise of constituent power by Māori to sanction the constitutional change.

81 Cabinet Minutes "Consideration of Constitutional Issues" (6 December 2010) CAB (10) M 44/3.

82 Ibid. 


\section{A Electoral Changes}

The electoral system directly affects the functioning of representative democracy, a key element of the New Zealand Constitution. ${ }^{83}$ Representative democracy, operating through Parliament, in turn connects with the fundamental political decision to share authority between Māori and the Crown. Including a sufficient Māori voice in the law-making process, at both a central and local government level, is an important means of ensuring that Māori have a share of authority to govern their people in the current New Zealand framework. ${ }^{84}$ This section focuses on Māori seats in Parliament and changes to Parliament's size and term, excluding possible electoral system changes in light of the result of the November 2011 public referendum electing to retain the MMP system.

\section{Māori seats in Parliament}

The Māori seats in the House of Representatives are arguably the most direct means by which Māori have a share of authority in government. The 1986 Royal Commission on the Electoral System found Māori viewed the seats as an important expression of their constitutional position and a channel that gives effect to their rights. ${ }^{85}$ The Royal Commission noted: ${ }^{86}$

Insofar as they have come to be regarded by many Maori as the principal expression of their

Constitutional position in New Zealand, the Maori seats in Parliament are a powerful political symbol.

Matthew Palmer asserts that Māori political representation is especially significant given New Zealand's other constitutional elements - representative democracy and parliamentary sovereignty are majoritarian with reference to the wider New Zealand polity. ${ }^{87}$ The number of Māori seats, and the number of Māori each seat represents, are important measures of effective Māori authority in Parliament. Any decrease in the number or relative percentage of Māori seats, or diminution in the weight of a Māori vote as compared to general electorate votes, may be a breach of the fundamental political decision. Such a decrease would undermine the symbolic and effective share in law-making authority that Māori hold.

Further, if the current constitutional review discovered a desire by New Zealanders to amalgamate separate Māori representation with general representation in Parliament, it is submitted that an exercise of Māori constituent power would be required to enact this. This is because the fundamental political decision contemplates a distinct Māori input in governance. Abolishing an established, if not perfect, mechanism that Māori perceive enables them to have this distinct input

83 Matthew SR Palmer The Treaty of Waitangi in New Zealand's Law and Constitution, above n 33, at 282.

84 Ibid at 283.

85 Ibid at 251.

86 Ibid at 257.

87 Ibid at 291. 
seems to amount to Māori giving up their own constituent power. ${ }^{88}$ An argument against keeping Māori seats might be that Māori representation is sufficient now that the MMP representation system provides greater Māori representation for smaller parties. I disagree with that contention as Māori seats are a direct and exclusively Māori form of representation that guarantee Māori a share in authority. From the perspective of the fundamental political decision, seats could only be reduced with the support of Māori through an exercise of Māori constituent power. This view seems to have significant political recognition too, which demonstrates the impact of the fundamental political decision in the Treaty. For example, in 2001 the MMP Review Committee found that all political parties except for the ACT Party supported retaining Māori seats and: ${ }^{89}$

... considered that separate Maori electorates could be seen as one of the distinctive elements of the

New Zealand MMP system and should remain until such time as Maori determine the seats are no

longer required or seen as desirable.

\section{Other changes - length of Parliament's term and size}

Further electoral changes contemplated in the Constitutional Review are the length of the parliamentary term and whether or not to fix it, and the size of Parliament. ${ }^{90}$ These changes could impact on the fundamental political decision to share authority only so much as they affected the relative share of Māori representation in Parliament. So, if the number of seats in the House of Representatives increased, but the number of Māori seats remained constant, this would breach the fundamental political decision. However, if for example, the length of Parliament's term was made indefinite, while this clearly raises constitutional issues from a democratic standpoint, in terms of the authority share between Māori and the Crown, there would not be an issue so long as Māori were effectively represented in that Parliament.

\section{B Introduction of a Written Constitution or Codification}

As discussed throughout this article, the fundamental political decisions or elements of the New Zealand constitution determining our political existence currently reside in an unconsolidated state, in a variety of written and unwritten, and legal and extra-legal sources. The consolidation or realignment of the key elements into a written constitution could potentially alter the key elements of the constitution, depending on the manner and extent of the codification of the written constitution.

88 It is not asserted that the status quo perfectly enables Māori authority. However, reducing the authority Māori currently have would go against the fundamental political decision.

89 Inquiry into the Review of MMP: Report of the MMP Review Committee I.23A (House of Representatives, 2001) at 5; cited in Matthew SR Palmer The Treaty of Waitangi in New Zealand's Law and Constitution, above n 33, at 254 .

90 Cabinet Minutes "Consideration of Constitutional Issues", above n 81. 


\section{Extent of codification}

The extent of a potential codification of the constitution would determine the interaction of constitutional elements included and excluded in the constitutional document. The codification might be limited in scope; for example, it is likely that a formal constitutional document stating New Zealand's new arrangements would accompany the move towards a republic, but that need not cover other elements of the constitution such as certain basic rights.

If a written constitution included a codification of all the other key elements in the New Zealand constitution except for the share of authority between the Crown and Māori, this would breach the fundamental political decision. This is because exclusion in light of a codification of all other elements would infer that the sharing of authority was not a key element of the Constitution; and this is contrary to the exercise of Māori constituent power in the Treaty. Alternatively, if a new constitutional document consolidated some key elements of the Constitution, but excluded other existing elements of the constitution (including the share of authority in the Treaty), then in some circumstances this might not be in breach of the fundamental political decision in the Treaty. This would depend on the nature and effect of the included key elements and fundamental political decisions, and whether their inclusion could be consistent with the survival of the Treaty's fundamental political decision.

In the case of a constitutional document purporting to remove the fundamental political decision in the Treaty by excluding it or implying that it was overridden, an exercise of Māori constituent power would be required to sanction the document. If this requirement was not satisfied, Māori could challenge the new delegation of authority, and argue that the fundamental share of authority guaranteed in the Treaty remained a constitutional convention.

\section{Inclusion of the Treaty of Waitangi}

The strong political and constitutional arguments and Māori political pressure make it likely that at least some aspects of the Treaty of Waitangi would be included in a written Constitution. This might include the principles of the Treaty of Waitangi. It is submitted that an exercise of Māori constituent power would also be required to sanction the inclusion of the Treaty principles in a new written Constitution, because the inclusion would inevitably affect the fundamental political decision contained in the actual Treaty.

The courts and the Waitangi Tribunal have developed the principles of the Treaty in their respective and distinct jurisdictions to interpret the Treaty of Waitangi. The Waitangi Tribunal recognises seven principles: the acquisition of sovereignty in exchange for the protection of rangatiratanga; that the Treaty established a partnership, and imposes on the partners the duty to act reasonably and in good faith; the freedom of the Crown to govern; the Crown's duty of active protection; the Crown's duty to remedy past breaches; that Māori retain rangatiratanga over their 
resources and taonga and have all the rights and privileges of citizenship; and finally, the duty to consult. ${ }^{91}$ A written constitution might specifically include some or all of the principles that are currently recognised, or simply a reference to the principles in general. Importantly, the principles are not fundamental political decisions. Rather, they are the interpretations of the relationship created between Māori and the Crown by the Treaty for the purpose of the specific jurisdictional functions of the courts and the Waitangi Tribunal.

Some of the principles can be seen to touch on the political existence of the New Zealand State, and the fundamental political decision in the Treaty, so far as they touch on the share of authority between Crown and Māori, such as the tension between the freedom of the Crown to govern and the reservation and protection of Māori rangatiratanga. However, the principles do not unequivocally guarantee the share of authority between Māori and the Crown as a key element of the Constitution, especially as the principles are open to interpretation and change, and have not been derived for the purpose of defining the key elements of the New Zealand Constitution. Certainly, a general reference to the Treaty principles in the codified constitution could undermine the share of authority between the Māori and the Crown. This is because the constitutional element of the Treaty would become the principles, with the problems just outlined, rather than the Treaty itself, which actually contains the fundamental political decision. As the Waitangi Tribunal warns, "the provisions of the Treaty itself should not be supplanted by the principles emerging from it". ${ }^{92}$

\section{Entrenchment procedures and supreme law status}

The effect of entrenchment provisions and the supreme law status of constitutional elements on constituent power is a grey area under Schmitt's conception of constituent power. Overall, this section of this article finds that the inclusion of entrenchment provisions in a new constitutional document, whether or not particular elements are accorded supreme law status, would not make a difference to the requirement that the overriding of the fundamental political decision in the Treaty requires the distinct exercise of constituent power by Māori.

On the one hand, the entrenchment of constitutional elements may act as an indicator that a particular element is a fundamental political decision, and requires an exercise of constituent power to remove or significantly amend it. The entrenchment procedure itself might promote popular participation and the constituent power by the people, which arguably promotes the democratic legitimacy of the Constitution. ${ }^{93}$ On the other hand, following Schmitt's theory, even fundamental political decisions without entrenchment require an exercise of constituent power to overturn them. Further, as discussed in Part II of this article, strict legal procedures to amend certain elements of the

91 Janine Hayward "Appendix: The Principles of the Treaty of Waitangi" The Waitangi Tribunal $<$ www.waitangi-tribunal.govt.nz>.

92 Ibid at 475.

93 Joel Colón-Riós "New Zealand's Constitutional Crisis", above n 22, at 456. 
constitution cannot bind the constituent power, as it is an extra-legal power. Whether a constitutional element has supreme law status in a written constitutional document - so that the courts could overturn legislation that is not in line with that element - is arguably just as superfluous under Schmitt's theory, since all fundamental political decisions are principles that are above the law anyway, and require an exercise of constituent power to overturn or significantly change them.

If a new constitutional document set up special amendment procedures and supreme law status for only particular key elements of the Constitution, not including the decision to share authority between the Crown and Māori, it would not necessarily be inconsistent with the fundamental political decision in the Treaty. Māori could argue that the fundamental political decision, in accordance with Schmitt's theory of constituent power, stands until overturned by those who created the decision through constituent power, regardless of the lack of formal entrenchment procedures. The theory of constituent power would also hold that Parliament could not make laws inconsistent with the fundamental political decision. On the other hand, entrenchment of some elements and not the decision to share authority suggests on its face that the former elements are more important and are better protected. Further, it would indicate Parliament could pass laws that impinge on the fundamental political decision to share authority, even though this would be unconstitutional according to Schmitt.

Sir Geoffrey Palmer has argued for the codification and accordance of supreme law status to New Zealand's key constitutional elements because in the absence of written form and being accorded supreme law status they are too easily subject to political forces: ${ }^{94}$

New Zealand's Constitution is essentially political. That is to say its workings depend on political factors and what happens depends largely on the will of the politicians. It is that feature of it that raises issues of concern about the absence of a robust template. There is just not enough form and process laid down - a framework too incomplete with insufficient rules - too much is left at large ... So is the fact that much of it is not justiciable, and therefore, is not enforceable.

This section does not attempt to resolve whether a written constitutional document should give supreme law status to the constitutional elements. Rather, it has used the hypothetical scenario of the fundamental political decision to share authority being excluded from supreme law status and entrenchment to point out that following Schmitt's theory of constituent power strictly, these protections are not needed to preserve the fundamental political decision. The fundamental political decision in the Treaty can be overturned or changed, but only by an exercise of Māori constituent power.

94 Geoffrey Palmer "The Hazards of Making Constitutions: Some Reflections on Comparative Constitutional Law" (2002) 33 VUWLR 631 at 638-642. 


\section{The transformation of New Zealand into a republic}

The transformation of New Zealand into a republic is a potential constitutional change that would most likely involve a codification process. The significant academic support for separate Māori assent, based on the Treaty of Waitangi, to transform New Zealand into a republic demonstrates recognition that an exercise of Māori constituent power is required where constitutional codification or transformation would infringe on the fundamental political decision to share authority between the Crown and Māori.

Matthew Palmer has recently argued that: ${ }^{95}$

Maori have by now established sufficient symbolic and legal linkages with 'the Crown', through the Treaty of Waitangi, to be able to exert significant raw political leverage on the design of the constitutional arrangements that propose to do without a Crown.

Likewise, Lord Cooke, in considering the positive reaction of the judiciary to a move to a republic asserted that, "... it is not easy to believe that a Court could responsibly hold republicanism lawfully established without reasonably substantial Maori concurrence". ${ }^{96}$ FM Brookfield also mandates Māori assent as a necessary prerequisite to a court legitimately recognising the republican shift. ${ }^{97}$ At first, the language of these opinions in talking about the legality of the constitutional change to a republic appears to be inconsistent with the theory of constituent power, in which the key elements of the constitution exist above the law. However, in essence Lord Cooke and FM Brookfield are arguing that a fundamental constitutional change to a republic is above ordinary legal processes and the legal duty of the court to enforce the law change if process is followed. What is needed to make the change legitimate is approval by the people. This view does not treat the change to a republic as within the ordinary legal framework, but rather argues an exercise of constituent power is necessary over and above any legal change. Brookfield additionally references, at least indirectly, principles of constituent power as part of his basis for requiring both Māori and Pākehā involvement in the process. In 1995, he commented that: ${ }^{98}$

... the abolition of the monarchy can only take place by revolution which courts might validate or recognise if new "facts of Constitutional life" were sufficiently strong to prompt them to do so.

The proof of new "facts of Constitutional life", which Brookfield asserts would satisfy a court would be in the form of a statute abolishing the Monarchy, passed by Parliament with a virtually

95 Matthew SR Palmer The Treaty of Waitangi in New Zealand's Law and Constitution, above n 33, at 248.

96 Robin Cooke "The Suggested Revolution Against the Crown" in Philip Joseph (ed) Essays on the Constitution (Brookers, Wellington, 1995) 28 at 38.

97 FM Brookfield "The Treaty, the 1840 Revolution and Responsible Government", above n 32, at 317.

98 Ibid at 317. 
unanimous House of Representatives and with the support of separate Māori and Pākehā referendums. What Brookfield appears to be requiring in addition to legislation, is a separate exercise of constituent power by both Māori and non-Māori, in order to effect the major constitutional change of transforming New Zealand into a republic. The new "facts of Constitutional life" are the equivalent of a fundamental political decision that is a key element of the Constitution, and has support from those with the political will - Māori and non-Māori.

\section{OPTIONS FOR EXERCISING MĀORI CONSTITUENT POWER TO APPROVE CONSTITUTIONAL CHANGES}

Part V has argued that constitutional changes that would infringe the fundamental political decision in the Treaty to share authority between the Crown and Māori require a further exercise of Māori constituent power to sanction. The purpose of Part VI is first to point out that non-Māori constituent power is potentially required as well as Māori constituent power in making these constitutional changes. Secondly, it proposes that the best option to accommodate both in compliance with Schmitt's conception of constituent power would be a joint democratically elected constitution-making assembly that drafted the constitutional changes that were then approved by separate referendums for Māori and non-Māori.

\section{A Māori and Non-Māori Constituent Power}

Arguably, both the scenarios of a change to a republic and the adoption of a written constitution would potentially invoke the exercise of constituent power by non-Māori. This is because the changes would potentially equate to fundamental political decisions - changing key elements of the Constitution, as well as affecting the fundamental political decision in the Treaty to share authority between Māori and the Crown. Applying Schmitt's concept of constituent power, all New Zealanders, including non-Māori, should exercise constituent power in the formation of these other fundamental political decisions, because they are part of 'the people' who, in a democracy, Schmitt identifies as holding constituent power. Bruce Harris, in considering the reaction of the courts to a new, supreme-law written constitution in New Zealand, states; "the courts would look for evidence of widespread community support" of such a constitution, probably in the form of a public referendum. 99 This supports the argument that the introduction of a written, supreme-law constitution equates to a significant constitutional change, and more importantly, that it requires an exercise of constituent power by both Māori and non-Māori to make such a change.

The fundamental political decision in the Treaty means that it is essential that a specifically Māori exercise of constituent power is required for any change that would overturn the fundamental political decision. There therefore needs to be a mechanism for the separate exercise of Māori constituent power in the adoption of a written constitution or a move to a republic (or both together);

99 Bruce Harris "Constitutional Change" above n 76, at 119. 
alongside a general exercise of constituent power to sanction the other fundamental political decisions involved.

\section{B The Best Option}

In Part II of this article a list of plausible ways to exercise constituent power in a modern democracy according to Schmitt and Kalyvas was recounted. This section analyses the potential for the second option (a democratically elected constitution-making assembly that drafts the constitution and constitutional laws that are passed by a referendum vote) and the fourth option (a general popular vote on a proposed constitution or constitutional change) that Schmitt listed. I argue that the second option is the most democratically legitimate. I discount Schmitt's first option (a democratically elected constitution-making assembly that passes the constitution and constitutional laws by its own majority vote), and third option (a constitutional assembly that submits the drafted constitution to each federal state for assent): The first option is dismissed on the basis that one elected constituent assembly voting itself on the constitutional changes cannot accommodate the requirement for separate Māori and non-Māori constituent power, and the third option on the basis that it refers to a federal state structure and so is not relevant to New Zealand.

The second of Schmitt's suggested options provides for a democratically elected constitutionmaking assembly that drafts the constitution and constitutional laws that then require a referendum vote to pass. The model could easily accommodate the separate Māori exercise of constituent power by requiring simultaneous Māori and non-Māori referenda to pass the constitution and constitutional laws issuing from a joint assembly. In the election for the constituent assembly, Māori should have direct representation - at least proportionate to the number of Māori seats in the House of Representatives. Politically, the joint Māori and non-Māori assembly would entail compromise, in order to have the drafted constitution accepted by both referenda, because each referendum would be able to veto passing the Constitution.

Schmitt's fourth option involves a general popular vote (referendum) on a draft constitution proposed by an unidentified source. This option would also work if there was a separate referendum for Māori and for non-Māori. However, it seems likely that, in New Zealand, Parliament would draft the constitution and constitutional laws. As Parliament is a constituted power, under Schmitt's theory it is not the ideal body to draft fundamental political decisions. As discussed in Part II, this risks the conflation of constituted and constituent power, with the latter absorbed by the former. An elected constituent assembly separate from Parliament, as in option two, is more democratic in terms of constituent power because it enhances the people's participation by giving them a choice of representation for the distinct purpose of drafting fundamental political decisions. Nevertheless, the referenda by Māori and non-Māori still provide that constituent power exists in option four.

Both the second and fourth options are in accordance with the concept of constituent power, and would provide for separate Māori constituent power. The second option is preferable because it better promotes constituent power at the drafting stage. 


\section{CONCLUSION}

In a democracy, according to Schmitt's theory of constituent power, the people possess the power to make fundamental political decisions to determine the form of their political existence. Applying this theory of constituent power to the Treaty of Waitangi, this article has found that in New Zealand Māori exercised constituent power by assenting to the Treaty. In doing so, Māori made a fundamental political decision which, taken from the Māori text and understanding of the Treaty, is to share authority in the New Zealand State between the Crown and Māori.

This fundamental political decision equates to the first key element of the New Zealand constitution and is comparable to a constitutional convention in that it is a binding obligation that is enforceable politically, rather than legally. Applying Schmitt's theory of constituent power further, this fundamental political decision in the Treaty affects New Zealand's constitution and law by placing restrictions on potential constitutional changes - prohibiting changes that would change or override the fundamental political decision to share authority, unless Māori exercise constituent power again to sanction those respective changes. It was argued that the adoption of a written constitution and the transformation to a republic are two such changes that would require Māori constituent power if they are to be legitimate constitutional changes.

The article considered how Māori might exercise constituent power again in potential constitutional changes, in particular in relation to the adoption of a written Constitution. It is submitted that the best option to pass constitutional changes would be a joint democratically elected constitution-making assembly that drafted the constitutional changes, to then be approved by two separate referenda for Māori and non-Māori. Essentially, a significant change to the fundamental political decision in the Treaty would be legitimate if Māori exercised constituent power to assent to the change through the means mandated. The extent of change to the fundamental political decision to share authority would be a question of fact, depending on the scope of the constitutional changes involved. Whatever that extent was, would become a new fundamental political decision and key element of the Constitution.

Finally, a second set of implications of the fundamental political decision, understood in Schmitt's terms, has not been explored in this article. This is that, as a fundamental political decision made by the people, the decision in the Treaty to share authority needs to be recognised in all subsequent key elements of the Constitution, constitutional laws, and all ordinary laws. Arguably, there are many ways in which the status quo does not currently respect the substance of the fundamental political decision. For example, two particular shortcomings that require change to comply with the decision to share authority are arguably in the area of resource management, ${ }^{100}$ and

100 Tikitu Tutua-Nathan "Kaitiakitanga: A Commentary on the Resource Management Act 1991" in Janine Hayward (ed) Local Government and the Treaty of Waitangi (Oxford University Press, South Melbourne, 2003) 39; Ronda Cooper "The Importance of Monsters: A Decade of RMA Debate" in Janine Hayward (ed) Local Government and the Treaty of Waitangi (Oxford University Press, South Melbourne, 2003) 95; Erin 
the criminal justice system. ${ }^{101}$ To the extent that the share of authority between the Crown and Māori in the status quo departs from the commitment to share authority recorded in the Treaty, it detracts from the democratic legitimacy of the current New Zealand framework, if analysed in terms of constituent power. This article broaches the conservative obligations of characterising the Treaty as a fundamental political decision. The aspirational implications that might apply to the current arrangements in New Zealand represent another analysis that might usefully be informed by this characterisation of the Treaty.

Thompson "Māori and Natural Resource Management" (2007) 7 BRMB 87 at 91; Elizabeth Clark "Section 33 of the Resource Management Act 1991" in Janine Hayward (ed) Local Government and the Treaty of Waitangi (Oxford University Press, South Melbourne, 2003) 41; Natalie Coates "Joint-Management Agreements in New Zealand: Simply Empty Promises?" (2009) 13 J South Pac Law 32.

101 Moana Jackson "Criminality and the exclusion of Māori" (1990) 20 VUWLR 23; Moana Jackson, "Cultural Justice: A Colonial Contradiction or a Rangatiratanga Reality?" in FWM McElrea (ed) Rethinking Criminal Justice: Justice in the Community (Legal Research Foundation, Auckland, 1995) vol 1 at 34. 
